\title{
The Benthic Fauna and Water Physicochemical Characteristics in the Estuarine Ecosystem of the Mouth of Moulouya River (Morocco)
}

\author{
Darif $\mathrm{H}^{1 *}$, El Guamri $\mathbf{Y}^{1,2}$, Amahmid $\mathbf{0}^{2,4}$, Razoki $\mathrm{B}^{3}$, El Madhi \\ Y1,5 ,Barkia H¹, El Halouani H' ${ }^{6}$, El Kharrim ${ }^{1}$ and Belghyti D1 \\ ${ }^{1}$ Laboratory of Biotechnology, Environment and Quality (LABEQ), Faculty of Sciences, \\ Ibn Tofaïl University of Kenitra Morocco
}

2Biology Unit, Regional Centre of the Trades of Education and Training "CRMEF" of Marrakesh, Morocco

${ }^{3}$ Geology Unit, Regional Centre of the Trades of Education and Training “CRMEF” of Marrakesh, Morocco ${ }^{4}$ Laboratory of Hydrobiology, Ecotoxicology and Assainissment (LHEA), Faculty of Sciences Semlalia, Cadi Ayyad University, Marrakesh, Morocco

${ }^{5}$ Research Team: Education, Environment and Health, Regional Centre of the Trades of Education and Training “CRMEF” of Rabat, Morocco

${ }^{6}$ Laboratory of Water Sciences, Environment and Ecology, Faculty of Sciences, University of Mohammed First, Oujda, Morocco

*Corresponding author: H Darif, Laboratory of Biotechnology, Environment and Quality (LABEQ), Faculty of Science, Ibn Tofail University, BP133, 14000 Kenitra, Morocco, Tel: +212 662730314; E-mail: youhajar@yahoo.fr

\section{Abstract}

Moulouya is the most important river of Morocco flowing into the Mediterranean Sea. The present study was carried out to assess the impact of anthropogenic activities on the distribution and biodiversity of benthic fauna as well as water quality in the Moulouya River estuary area, Oriental region, Morocco. Three stations at the downstream receiving anthropogenic impacts were selected along the river estuary. Physicochemical characteristics of the river water including temperature, $\mathrm{pH}$, salinity, DO, conductivity, $\mathrm{SM}, \mathrm{Cl}^{-}, \mathrm{NH}_{3}, \mathrm{PO}_{4}^{3-}, \mathrm{NO}_{3}-, \mathrm{NH}_{3}-\mathrm{N}, \mathrm{COD}$ and BOD were investigated. The study of the current state of the benthic fauna stationed at the mouth of the river resulted in 22 detected species distributed in 4 classes. Crustaceans were the most frequently collected with 4 inventoried types accounting for $43.5 \%$ (236/542). Molluscs represented 38.2\% (207/542) of the collected specimens and Melanopsis costellata was the most abundant species. The investigation of the physicochemical parameters revealed water quality degradation mainly due to discharged organic matter of industrial and municipal effluents without proper treatment. The present study findings 


\section{Journal of Ecology \& Natural Resources}

may allow updating data regarding the taxonomic inventory of the fauna as well as highlighting the water quality status in the estuarine ecosystem of the mouth of Moulouya River (Morocco).

Keywords: Benthic fauna; Estuarine ecosystem; Physicochemical parameters; Moulouya River; Morocco

Abbreviations: COD: Chemical Oxygen Demand; EC: Electrical Conductivity; DIN: Deutsche Institut fur Normung; BOD: Biochemical Oxygen Demand

\section{Introduction}

Estuaries act as a transitional zone between land and sea are considered as fragile ecosystem with unique physical, chemical and biological features [1]. They are complex and dynamic aquatic environment receiving considerable amounts of nutrients as well as anthropogenic wastes [2]. Moulouya River, originating in the southern part of the Middle Atlas, is the second largest fluvial system of North Africa draining into the Mediterranean Sea [3]. The mouth of the river and its marsh complex constitute a Site of Biological and Ecological Interest. It used to be a refuge for numerous birds of international and national interest, as well as the habitat of privileged and extremely diversified fauna and plant formations that are exceptional for Morocco $[4,5]$. In this sense, the knowledge of the benthic fauna of the rivers and Moroccan water plans have been a real concern for naturalists, scientists and organisms involved in sustainable development due to its richness and diversity $[6,7]$. In addition to climate change, the aquatic ecosystem of Moulouya River suffers from a severe and increasing degradation due to discharge of domestic, municipal, industrial, recreational and constructional activities in the catchment areas [8-11]. This anthropic activity, exacerbated by low and uneven rainfall has a major impact on aquatic biodiversity, such as benthic fauna. Also the water physico-chemical characteristics may be greatly affected. The current study was conducted to explore and update data on the distribution and biodiversity of the benthic fauna in the Moulouya River estuary and to assess the effects of the anthropic activity on this biodiversity and water quality through measurement and analysis of physicochemical parameters.

\section{Material and Methods}

\section{Study Area}

The current study was carried out in Oriental Region, Morocco. The Moulouya watershed is the largest river basin of Morocco with a surface area of about $54,500 \mathrm{~km}^{2}$, and covers much of the Oriental region. With a length of $520 \mathrm{~km}$, Moulouya River is the largest river in Morocco. Its sources are placed in the Atlas Mountains and flows into Mediterranean Sea near the Algerian border (Figure 1). The climate of the Moulouya Basin is of a semi-arid Mediterranean type, characterized by low and irregular precipitation with an annual pluviometric index ranging from 230 to $380 \mathrm{~mm}$ [12]. The study was conducted in the estuary area of Moulouya River (Morocco).

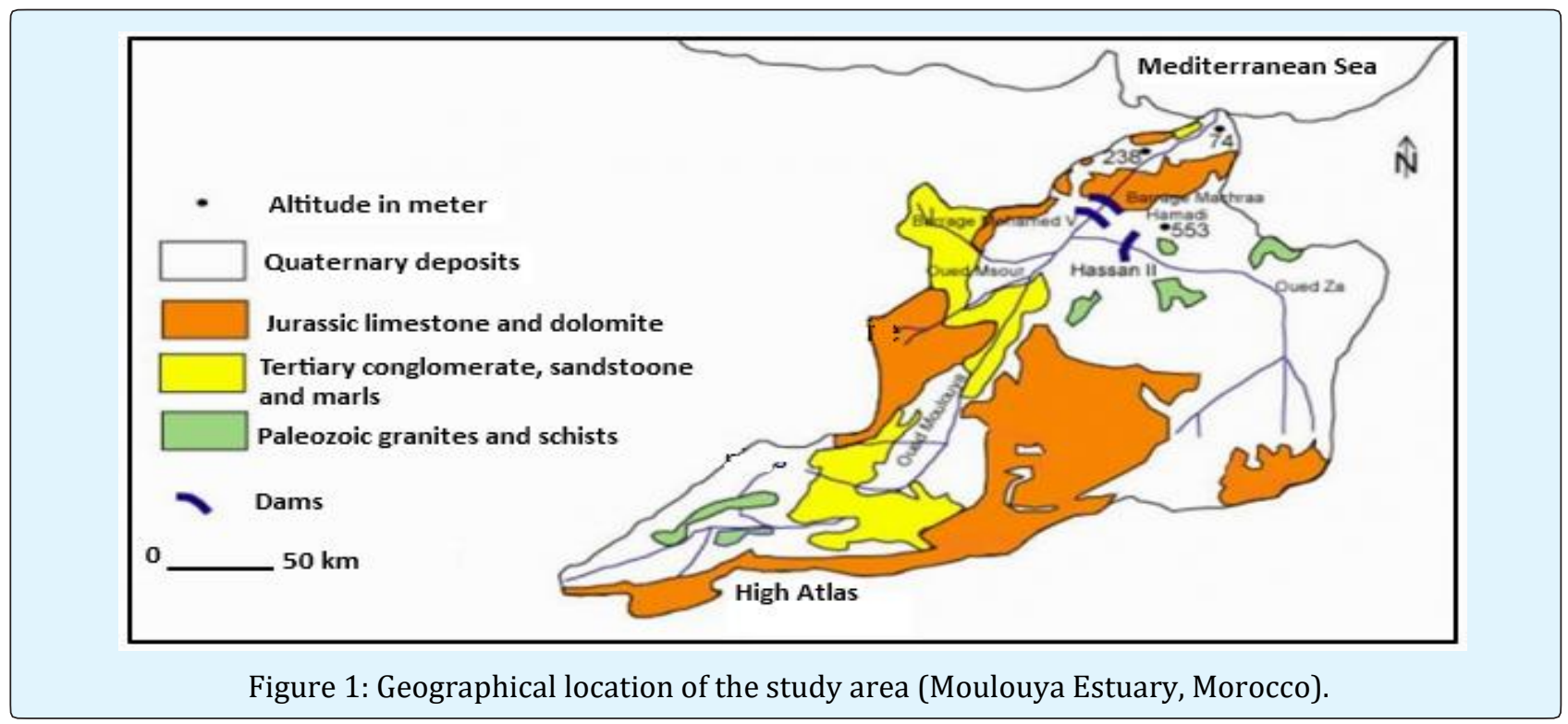

Darif $\mathrm{H}$, et al. The benthic fauna and water physicochemical characteristics in the estuarine ecosystem of the mouth of moulouya river (morocco). J Ecol \& Nat Resour 2018, 2(1): 117. 


\section{Journal of Ecology \& Natural Resources}

Three intertidal stations are distributed over the first 20.5 kilometers of the estuary zone and were located on the right bank (station 1 and 2) and the left bank (station 3):

- Station 1 (S1): located near a channel at $20 \mathrm{~km}$ upstream of the river mouth.

- Station (S2): located $10 \mathrm{~km}$ from the river's mouth, receiving urban and industrial liquid discharges of the city of Saïdia.

- Station (S3): located at the mouth of Moulouya River.

\section{Sampling Materials and Methods}

The sampling material used in the conducted study was a modified Juday-bogoroff's net $[13,14]$, with a conic shape and $120 \mathrm{CMs}$ length, fixed to posterior and anterior metallic rings with respective diameters of 32 and $24 \mathrm{~cm}$. The net was made with a silk mesh size $150 \mu \mathrm{m}$. At the end, the net is closed off with a plastic cylinder (cod-end) that collects the fauna $[15,16]$. Hard substrate and loose substrate (bare or with vegetation) have been explored.

On the hard substratum, a surface of $900 \mathrm{~cm}^{2}(30 \mathrm{~cm}$ $\mathrm{x} 30 \mathrm{~cm}$ ) was scratched; as it has been reported to be representative [17]. The sampling of the macro-fauna (macro-crowd) was undertaken at low tide.

The collected samples were fixed in $40 \%$ formalin then conserved in $10 \%$ estuary formalin water. Sorting the collected benthic fauna by size was made easy by using a column of 3 sieve meshes in a decreasing order $2 \mathrm{~mm}, 1$ $\mathrm{mm}$ and $0.3 \mathrm{~mm}$ [18]. The zoological groups were separated then conserved in $70 \%$ alcohol [19]. The species of every group were identified, and then counted. The identification of species was done using Binocular Stereo Zoom Microscope.

With regards to water quality, eleven hydrological parameters were investigated to characterize the estuary water: water temperature (Te), electrical conductivity (EC), dissolved oxygen (DO), $\mathrm{pH}$, suspended matter (SM), Chlorides, orthophosphate, nitrates (NO), ammonia nitrogen $\left(\mathrm{NH}_{3}-\mathrm{N}\right)$, chemical oxygen demand (COD) and biochemical oxygen demand (BOD).

Along the estuary of Moulouya River and throughout the study area, water samples were taken during wet period (March) and in dry period (July). Samples were collected in plastic bottles, pre-rinsed with water from the sampling station. The bottles were then transported to the laboratory at $4^{\circ} \mathrm{C}$. The water temperature was measured "in-situ" using a mercury thermometer graduated $1 / 10$ from 0 to $50{ }^{\circ} \mathrm{C}$. The hydrogen potential $(\mathrm{pH})$, electrical conductivity (EC) and dissolved oxygen (DO) were determined using a CONSORT-Model 835 multi- parameter analyzer. The suspended matter (SM) was determined by filtering a volume of water through a cellulosic filter $(0.45 \mu \mathrm{m}$ pore size) according to the protocol described by Rodier [20]. The $\mathrm{BOD}_{5}$ was evaluated by the method based on respiration measurement using a BOD-meter brand WTW, model 1020T following the technique described by the German Institute for Standardization (DIN) [21]. The COD was determined by refluxing the sample with excess of potassium dichromate in acid condition (at $148^{\circ} \mathrm{C}$ ) and estimated by titration to find amount of dichromate consumed which is directly proportional to COD as described in the literature [22]. Chlorides were assessed in acid solution $\left(\mathrm{HNO}_{3}\right)$ by direct titration with a standard mercuric nitrate solution, using a $\mathrm{pH}$ indicator. Nitrates, ammonium and orthophosphates were analyzed by colorimetric methods using a Visible Type 722 S Beijing UV spectrophotometer.

\section{Results}

\section{Investigation of the Physical-Chemical Characteristics}

Samples taken at the study site were analysed to determine the physico-chemical properties of the estuary water and assess temporal and spatial variations of hydrological parameters.

With regards to temporal variations, on the basis of the analyses results, the mean values and standard deviations were calculated over time during the dry period (March) and wet period (July) for all of the investigated parameters. The obtained results are summarized in Table 2. Water temperatures ranged from $13-25^{\circ} \mathrm{C}$, with minimum and maximum values in March 2014 and July 2014, respectively. A slight difference in water $\mathrm{pH}$ between the dry and wet periods was recorded with respective levels of 7.1 and 6.97. Significant higher levels of DO, COD, NH3-N and EC were recorded during the wet period compared to dry period. Conversely, for BOD, SM, $\mathrm{PO}_{4}{ }^{3-}, \mathrm{NO}^{3-}$ and $\mathrm{Cl}^{-}$, the highest concentrations were recorded during the dry period. A significant negative correlation ( $\mathrm{r}=-0.617 ; p<0.01$ ) was observed between Suspended Matter and DO, indicating that the DO is largely influenced by the SM. 


\section{Journal of Ecology \& Natural Resources}

\begin{tabular}{|c|c|c|}
\hline \multirow{2}{*}{ Physicochemical parameters } & \multicolumn{2}{|c|}{ Sampling period } \\
\cline { 2 - 3 } & Dry period (March) & Wet period (July) \\
\hline Temperatures $\left({ }^{\circ} \mathrm{C}\right)$ & $25 \pm 0.5$ & $13 \pm 1.5$ \\
\hline Potential hydrogen $\mathrm{pH}$ & $7.10 \pm 0.5$ & $6.97 \pm 1.5$ \\
\hline Electrical Conductivity $\mathrm{EC}(\mu \mathrm{s} / \mathrm{cm})$ & $1100 \pm 200$ & $1250 \pm 150$ \\
\hline Suspended Matter SM $(\mathrm{mg} / \mathrm{l})$ & $750 \pm 90$ & $500 \pm 120$ \\
\hline Dissolved Oxygen DO $(\mathrm{mg} / \mathrm{l})$ & $5.5 \pm 2.5$ & $8.9 \pm 1.5$ \\
\hline Biochemical Oxygen Demand BOD $(\mathrm{mg} / \mathrm{l})$ & $21 \pm 10$ & $7 \pm 5.5$ \\
\hline Chemical Oxygen Demand COD $(\mathrm{mg} / \mathrm{l})$ & $25 \pm 12.5$ & $30 \pm 5.5$ \\
\hline Chlorides $\mathrm{Cl}-(\mathrm{mg} / \mathrm{l})$ & $356 \pm 135.5$ & $0.08 \pm 0.3$ \\
\hline Orthophosphate $\mathrm{PO}_{4}{ }^{3-}(\mathrm{mg} / \mathrm{l})$ & $0.13 \pm 0.5$ & $0.1 \pm 0.5$ \\
\hline Nitrates $\mathrm{NO}_{3}-(\mathrm{mg} / \mathrm{l})$ & $0.15 \pm 0.5$ & $0.0071 \pm 0.002$ \\
\hline Ammonia nitrogen $\mathrm{NH}_{3}-\mathrm{N}(\mathrm{mg} / \mathrm{l})$ & $0.001 \pm 0.003$ & \\
\hline
\end{tabular}

Table 2: Seasonal variation of water physicochemical characteristics

The spatial variation of the investigated physicochemical parameters was evaluated along the transect S1-S2-S3. The obtained results are presented in Table 3. Water temperature as well as $\mathrm{pH}, \mathrm{BOD}, \mathrm{Cl}^{-}, \mathrm{NO}_{3}{ }^{-}$ and NH3-N levels were found to be significantly higher in
S1 (upstream) as compared to those recorded in S2 and S3. An increase in DO, COD and $\mathrm{NO}_{3}{ }^{-}$concentrations was detected in S2 waters in comparison to S1 and S3, while the highest values of $\mathrm{EC}, \mathrm{SM}$ and $\mathrm{PO}_{4}{ }^{3-}$ were found in $\mathrm{S} 3$ located at the mouth of the river.

\begin{tabular}{|c|c|c|c|}
\hline \multirow{2}{*}{ Physicochemical parameters } & \multicolumn{3}{|c|}{ Stations } \\
\hline & S1 & S2 & S3 \\
\hline Temperatures $\left({ }^{\circ} \mathrm{C}\right)$ & $25 \pm 0.5$ & $12 \pm 1.5$ & $13 \pm 1.5$ \\
\hline Potential hydrogen $\mathrm{pH}$ & $8 \pm 1.5$ & $6.97 \pm 1.5$ & $7.10 \pm 0.5$ \\
\hline Electrical Conductivity EC $(\mu \mathrm{s} / \mathrm{cm})$ & $1100 \pm 200$ & $1050 \pm 140$ & $1250 \pm 150$ \\
\hline Suspended Matter SM (mg/l) & $550 \pm 90$ & $480 \pm 120$ & $750 \pm 90$ \\
\hline Dissolved Oxygen DO (mg/l) & $5.5 \pm 2.5$ & $8.1 \pm 1.5$ & $6.1 \pm 2.5$ \\
\hline Biochemical Oxygen Demand BOD (mg/l) & $21 \pm 10$ & $4.5 \pm 0.5$ & $7 \pm 5.5$ \\
\hline Chemical Oxygen Demand COD (mg/l) & $22 \pm 2.5$ & $28 \pm 5.5$ & $25 \pm 12.5$ \\
\hline Chlorides $\mathrm{Cl}^{-}(\mathrm{mg} / \mathrm{l})$ & $356 \pm 135.5$ & $222 \pm 10$ & $347 \pm 125.5$ \\
\hline Orthophosphate $\mathrm{PO}_{4}^{3-}(\mathrm{mg} / \mathrm{l})$ & $0.08 \pm 0.3$ & $0.10 \pm 0.3$ & $0.13 \pm 0.5$ \\
\hline Nitrates $\mathrm{NO}_{3}{ }^{-}(\mathrm{mg} / \mathrm{l})$ & $0.15 \pm 0.5$ & $0.5 \pm 0.5$ & $0.1 \pm 0.5$ \\
\hline Ammonia nitrogen $\mathrm{NH}_{3}-\mathrm{N}(\mathrm{mg} / \mathrm{l})$ & $0.011 \pm 0.003$ & $0.0071 \pm 0.002$ & $0.001 \pm 0.003$ \\
\hline
\end{tabular}

Table 3: Spatial variation of water physicochemical characteristics

\section{Investigation of the Benthic Fauna}

The results of the collected benthic fauna from the mouth of Moulouya River made it possible to identify the current state of species biodiversity belonging to four classes (Figure 2). A total of 542 invertebrates were collected. Molluscs were the most abundant with $38.2 \%$ $(207 / 542)$ rate. They were represented by 2 orders: Gastropods and Bivalves. In contrast, insects were the minority class in term of diversity (represented only by Diptera), with abundance level similar to that recorded for the Annelids. 


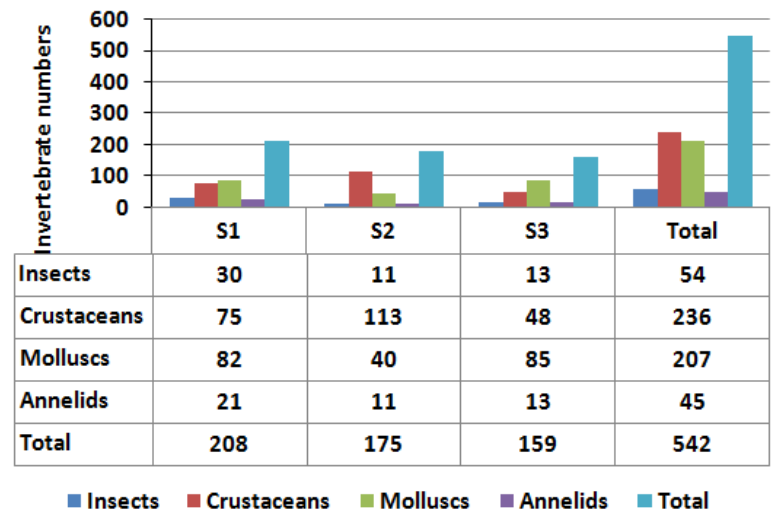

Figure 3: Spatial evolution of the benthic fauna of the Moulouya River estuary from upstream (S1) to downstream (S3).
The benthic species encountered during the various field sampling missions are listed in Table 3. Four systematic groups, 22 species were inventoried during the two sampling campaigns carried out on the benthic macrofauna of the infra-littoral floor within the estuary of Moulouya (Morocco). For the distribution of species by systematic groups, 12 species were molluscs with $54.5 \%$ of total species number (36.4\% of Gasteropods vs. $18.2 \%$ of Bivalvia); 4 species of Crustacea (18.2\%); 3 species of Insects (13.6\%) and 3 species of Annelids, Oligochaetes (13.6\%).

\begin{tabular}{|c|c|c|c|c|c|}
\hline Class & Order & Species & Station 1 & Station 2 & Station 3 \\
\hline \multirow{3}{*}{ Insects } & \multirow{3}{*}{ Diptera } & Prodiamesa olivacea & + & - & + \\
\hline & & Chironomus sp. & + & + & + \\
\hline & & Glyptotendipes sp. & + & + & + \\
\hline \multirow{4}{*}{ Crustaceans } & Decapods & Atyaephyra desmarestii & - & + & + \\
\hline & Thoracic & Balanus montagui & - & + & + \\
\hline & Isopods & Asellus sp. & + & - & + \\
\hline & Amphipods & Gammarus gauthieri & + & + & - \\
\hline \multirow{12}{*}{ Molluscs } & \multirow{8}{*}{ Gastropods } & Melanopsis cariosus & + & - & + \\
\hline & & Melanopsis costellata & + & + & + \\
\hline & & Margaritifera margaritifera & + & + & + \\
\hline & & Cerithium rupestre & - & + & + \\
\hline & & Murex brandaris & + & + & + \\
\hline & & Philbertia leurfroyi & + & - & + \\
\hline & & Nassa pfeifferi & + & + & + \\
\hline & & Pyrene broderipi & - & + & + \\
\hline & \multirow{4}{*}{ Bivalves } & Donax venustus & + & + & - \\
\hline & & Cardium edule & + & - & + \\
\hline & & Gafrarium minimum & + & - & + \\
\hline & & Glycymeris glycymeris & - & + & + \\
\hline \multirow{3}{*}{ Annelids } & \multirow{3}{*}{ Oligochaetes } & Lumbriculidae sp. & + & + & - \\
\hline & & Eiseniella tetraedra & - & - & + \\
\hline & & Himantopus himantopus & + & + & + \\
\hline
\end{tabular}

(+) Presence; (-) absence.

Table 3: Checklist of benthic fauna collected at stations S1-S3 at the Moulouya River estuary. 


\section{Journal of Ecology \& Natural Resources}

\begin{tabular}{|c|c|c|c|c|c|c|}
\hline Class & Order & Species & S1 & S2 & S3 & Total \\
\hline \multirow{3}{*}{ Insects } & \multirow{3}{*}{ Diptera } & Prodiamesa olivacea & 16 & - & 8 & 24 \\
\hline & & Chironomus sp. & 2 & 1 & 2 & 5 \\
\hline & & Glyptotendipes sp. & 12 & 10 & 3 & 25 \\
\hline \multirow{4}{*}{ Crustaceans } & Decapods & Atyaephyra desmarestii & - & 90 & 21 & 111 \\
\hline & Thoracic & Balanus montagui & - & 10 & 12 & 22 \\
\hline & Isopods & Asellus sp. & 55 & - & 15 & 70 \\
\hline & Amphipods & Gammarus gauthieri & 20 & 13 & - & 33 \\
\hline \multirow{12}{*}{ Molluscs } & \multirow{8}{*}{ Gastropods } & Melanopsis cariosus & 11 & - & 22 & 33 \\
\hline & & Melanopsis costellata & 30 & 20 & 25 & 75 \\
\hline & & Margaritifera margaritifera & 10 & 2 & 8 & 20 \\
\hline & & Cerithium rupestre & - & 11 & 5 & 16 \\
\hline & & Murex brandaris & 2 & 2 & 4 & 8 \\
\hline & & Philbertia leurfroyi & 20 & - & 5 & 25 \\
\hline & & Nassa pfeifferi & 6 & 1 & 3 & 10 \\
\hline & & Pyrene broderipi & - & 1 & 10 & 11 \\
\hline & \multirow{4}{*}{ Bivalves } & Donax venastus & 1 & 1 & - & 2 \\
\hline & & Cardium edule & 1 & - & 1 & 2 \\
\hline & & Gafrarium minimum & 1 & - & 1 & 2 \\
\hline & & Glycymeris glycymeris & - & 1 & 2 & 3 \\
\hline \multirow{3}{*}{ Annelids } & \multirow{3}{*}{ Oligochaetes } & Lumbriculidae sp. & 1 & 1 & - & 2 \\
\hline & & Eiseniella tetraedra & - & - & 1 & 1 \\
\hline & & Himantopus himantopus & 20 & 10 & 12 & 42 \\
\hline & & & 208 & 175 & 159 & 542 \\
\hline
\end{tabular}

Table 4: The number of species found in the estuary of Moulouya River (Morocco)

As shown in Table 3 and Table 4 a spatial variation was recorded in the occurrence of benthic fauna species along the Moulouya River estuary. The distribution of species by sampling station revealed that the station S1 contained 16 of 22 of the identified species, versus 15 species for S2 and 19 species for S3. In term of abundance, the upstream located station S1 had the highest abundance accounting for $38.4 \%(208 / 542)$ of the collected specimens, versus $32.3 \%$ for S2 while the lowest abundance was recorded in the downstream located station S3 with $29.3 \%$ of specimens. The Crustacean Atyaephyra desmarestii was the most abundant species $(20.5 \%)$ while the less frequently collected was the Annelid Eiseniella tetraedra $(0.2 \%)$ and occurred only in station 3 .

\section{Discussion}

Through the analyses of the physicochemical parameters of the water in the Moulouya River estuary, the current state of water quality, reflects the presence of a moderate to permanent pollution and localized near the city of Saïdia with significant spatiotemporal variations.

The recorded mean temperature around $20^{\circ} \mathrm{C}$ may be related to the local conditions. The recorded temperatures are similar to those reported by several studies in Morocco and other countries [23-25]. Comparative findings were reported by Ech-chafay and coll. indicating that such temperature levels $\left(20\right.$ to $\left.30^{\circ} \mathrm{C}\right)$ are favorable for bacterial growth (assimilative phenomenon), parasites, mosquito larvae and other microbial germs [26]. Conversely, the found temperature was lower than that recorded by El Morhit and coll. in the Loukous River estuary ranging from 15 to $35^{\circ} \mathrm{C}$ [27]. In the current study, the amplitude of temperature variation between the sampling points did not exceed $25^{\circ} \mathrm{C}$ suggesting that the Moulouya estuary was relatively homogeneous. Similarly, a higher amplitude variation was 


\section{Journal of Ecology \& Natural Resources}

reported in BouRegreg River with a range of 15 to $35^{\circ} \mathrm{Cwhich}$ might be due to natural factors and anthropogenic activities [28,29].

The conductivity measurement is a good assessment of the degree of mineralization of water in which each ion acts by its concentration and its specific conductivity. The increase of the electrical conductivity of water between the upstream (S1) and downstream (S3) of the Moulouya River estuary may be explained by the influence of marine waters and industrial discharges that penetrate inside the estuary, favored by the low slope of the main water course, leading to a significant increase in chloride ions. The recorded conductivity level did not exceed the Moroccan standards of surface water $(2700 \mu \mathrm{s} / \mathrm{cm})$ indicating low mineralization [30]. The mean values of conductivity observed in the ecosystem were lower than those reported in Sebou River estuary varying between 1200 and $1400 \mu \mathrm{s} / \mathrm{cm}$ [31]. However, they are much lower than those found in BouRegreg River fluctuating between 3430 and $8590 \mu \mathrm{S} / \mathrm{cm}$ [23]. The mean value of dissolved oxygen in this study was similar to that reported by Fekhaoui ranging from 6 to $9 \mathrm{mg} / \mathrm{L}$ [32]. However, it was lower than those reported by El Morhit and coll. in Loukouss River estuary and by El Blidi and Fekhaoui in Sebou river estuary $[27,33]$. The spatial evolution of the content of dissolved oxygen in the Moulouya River estuary revealed that the load of biodegradable organic matter originating from domestic, industrial and agricultural activities discharged into the river waters resulted in a significant decrease in the level of dissolved oxygen especially in S1 and S3. The excessive contributions of the organic fermentable matter rejected by sewers of Oujda city may explain the increase in dissolved oxygen consumption.

The analyses showed that average water $\mathrm{pH}$ in the Moulouya River estuary presented a slight, but no significant, variation remaining almost neutral. Other studies reported that $\mathrm{pH}$ may vary probably as a result of fluctuations in salinity following the tidal cycle and/or fluctuations in organic load [23,27]. The values of BOD and COD parameters found in the Moulouya river estuary are similar to those found by other authors [27]. Sarkar and coll. attributed the low concentration of chemical oxygen demand to the presence of organic matter [29]. The recorded spatial variation in BOD, COD, chlorides, orthophosphate, nitrates and ammonia nitrogen between stations may be due to the presence of pollution sources originating from the surrounding agglomerations.
In the Moulouya River, even with the low erosive potential of the watershed, waters are heavily charged in suspended matter, especially in S3 located at the downstream of the estuary (S3). These variations may be affected by the tidal regime as well as wide variations in hydrological parameters.

With regards to the benthic fauna, the collected species are divided into 8 orders belonging to 4 classes. Molluscs are the most numerous with 12 species. Insects, Annelids and Crustaceans come next with 3, 3 and 4 species, respectively. The species Atyaephyra desmarestii was the most frequently collected with a relative abundance of $20.5 \%$. Eiseniella tetraedra was collected from the class of oligochaetes with a relative abundance of $0.2 \%$.

The faunistic inventory resulted in four zoological groups of predominant invertebrates (Molluscs, Crustaceae and Oligochaetes) totaling 90.4\%, considered as the characteristic groups of the estuarine areas; in agreement with the findings of Benzakour and Mergaoui and al. in the estuaries of BouRegreg River and Sebou River, respectively [25,34].

The current study results showed that the constant and common forms belong to the Crustacean group. Thus, the carcinological fauna probably may be able to develop resistance to face different environmental aggressions as reported by Boussalwa in the same estuarine environment [35]. The silting up of the river mouth impedes access of fishing boats to the port. This leads to the reshaping of the substrate and its deposition in one place, hence the high number of mollusc species (12 species). Most of the malacological specimens were collected during the summer period between March and July 2014.

From a biogeographic point of view, the benthic fauna belongs to the Palearcticozone with the endemic Moroccan species from different groups [4,36]. This approach of the benthic population, through the classical descriptors (abundance, diversity ...) has shown that the benthic fauna collected at the mouth of Moulouya River is represented by a very large number of specialized taxa as compared to other researches by Fekhaoui and Dakki in upper Sebou, El Agbani in BouRegreg River and Badri in Tensift River [32,37-39]. This benthic community is also marked by the abundance of Gastropods (36.5\%) of the overall population collected in the mouth of Moulouya River. 


\section{Journal of Ecology \& Natural Resources}

\section{Conclusion}

The various physicochemical constituents in the Moulouya estuarine water showed spatial and temporal fluctuations. The level of measured parameters (i.e. DO, DBO, organic load...) revealed deterioration in water quality in the studied stations, especially in downstream stations, mainly due to domestic anthropogenic wastes.

The investigation of the benthic macrofauna provided a state of the art data on biodiversity of the estuarine invertebrate fauna of Moulouya River. However, the impact of physicochemical parameters may have on distribution and abundance of the benthic fauna was not investigated in this study.

Due to increasing pollution sources in the Moulouya River catchments, there is a fear of a serious deterioration in the water quality and biological diversity in the river estuary. Therefore, proper measures should be taken such as the treatment of sewage before discharge and restrictions of various anthropogenic activities affecting the health of the estuary ecosystem.

\section{References}

1. Anitha G, Sugirtha P Kumar (2013) Physicochemical characteristics of water and sediment in Thengapattanam estuary, southwest coastal zone. Int J of Enviro Sci 4(3): 205-222.

2. Shruthi MS, Sushanth VR, Rajashekhar M (2011) Diatoms as indicators of water quality deterioration in the estuaries of Dakshina Kannada and Udupi Districts of Karnataka. Int j of envir sci 2(2): 9961006.

3. Rixhon G, Bartz M, El Ouahabi M, Szemkus N, Brückner H (2016) Contrasting terrace systems of the lower MoulouyaRiver as indicator of crustal deformation in NE Morocco. J of African Earth Sci 126: 45-57.

4. Berrahou A, Cellot B, Richoux P(2001) Distribution longitudinale des macroinvertébrés benthiques de la Moulouya et de ses principaux affluents (Maroc). Ann Limnol Int J Lim 37(3): 223-235.

5. Snoussi M (2004) Review of certain basic elements for the assessment of environmental Flows in the Lower Moulouya. Gland, Switzerland: IUCN.

6. Fagrouch A, Berrahou A, El Halouani H (2011) The effects of an urban effluent from the city of Taourirt on macro-invertebrate community structure in the Zawadi, (Eastern Morocco). Rev Sci de l'Eau 24(2): 87-101.

7. Taybi FA, Mabrouki Y, Ghamizi M, Berrahou A (2017) The freshwater malacological composition of Moulouya's watershed and Oriental Morocco. J Mater Environ Sci 8(4): 1401-1416.

8. Doadrio I, Casal Lopez M, Perea S (2016) Taxonomic remarks on Barbus moulouyensis Pellegrin, 1924 (Actinopterygii, Cyprinidae) with the description of a new species of Luciobarbus Heckel, 1843 from Morocco. Graellsia 71(2): e054 [24].

9. Tekken V, Jürgen P, Kropp JP (2012) Climate-Driven or Human-Induced: Indicating Severe Water Scarcity in the Moulouya River Basin (Morocco). Water 4(4): 959-982.

10. Mabrouki Y, Taybi AF, Chavanon G, Vinçon G, Berrahou A (2016) Contribution to the study of stoneflies in eastern Morocco and the catchment area of the Moulouya and their distribution depending on the bioclimatic zones. J Mater Environ sci 7(6): 21782193.

11. Taybi AF, Mabrouki Y, Berrahou A, Chaabane K (2016) Spatiotemporal evolution of physicochemical parameters of the Moulouya River. J Mater Environ Sci 7(1): 272-284.

12. Tekken V, Costa L, Kropp JP (2009) Assessing the regional impacts of climate change on economic sectors in the low-lying coastal zone of Mediterranean East Morocco. J Coast Res SI 56: 272276.

13. Benbakhta B (1994) Structure and dynamics of the zooplankton of Moulay Bousselham (Morocco). Thesis Doct. 3rd cycle. Univ Mohammed V (Rabat), PP: 112.

14. Belghiti ML, Chahlaoui A, Bengoumi A (2013) physico-chemical characteristics of well waters used for drinking water supply in rural area in the region of Meknes (Morocco). Larhyss J 14: 21-36.

15. Lamri D, Belghyti D, Ibrahim M (2007) The impact of wastewater on water quality in the Moulouya River, Morocco. Trop Freshwater Biology 16(2): 1-8.

16. Chaoui W, Bousnoubra W, Chaoui K (2013) Study of the vulnerability to pollution of surface and 


\section{Journal of Ecology \& Natural Resources}

ground water in the Bouchegouf region. (Northeast Algeria). Revue Nature \& Technologie, C-Sciences of Environment 08.

17. Bitar G (1980) Etude de l'impact de la pollution par un émissaire urbain (collecteur Cortiou) sur les peuplements infralittoraux de substrats durs de la côte sud de Marseilleveyre (Marseille). Thèse Doctorat, Université Aix-Marseille 2.

18. Ben Mousa A, Chahlaoui A, Rour E (2013) Change of physico-chemical quality of Khoumane River waters near the city of Moulay Idris Zehroun, Morocco. Science Lib Editons Mersene 5(130308): 211-4706.

19. Azeroual A, CrivelliJ, Yahyaoui, Dakki M (2000) The ichthyofauna of the inland waters of Morocco. Cybium: international journal of ichthyology 24: 1722.

20. Rodier J (1996) L'analyse de l'eau, eaux naturelles, eau résiduaires, eau de mer, $7^{\text {th }}$ (Edn.), Dunod, 1383.

21. DIN German Institute of Standardisation (1992a) Détermination de la Demande Biologique en Oxygène (DBO) selon DIN Laboratoire National de l'Environnement, Rabat 1992.

22. DIN German Institute of Standardisation (1992b) Détermination de la Demande Chimique en Oxygène (DCO) selon DIN 38409-H52. Laboratoire National de l'Environnement - Rabat. 1992.

23. Nadem S, El Baghdadi M, Rais J, Barakat A (2015) Evaluation of heavy metal contamination of sediments of the estuary of the Bouregreg (Atlantic Coast, Morocco. J Mater Environ Sci 6(11): 33383345.

24. El Imrani Kh, Kettani K (2012) Hydromorphological disturbance and benthic fauna in Ez-zarka River (Martil watershed, Rif, Morocco). J of Mediterranean geography 118.

25. Mergaoui L, Fekhaoui M, Bouya D, Gheït A, Stambouli A (2003) Qualité des eaux et macrofaune benthique d'un milieu estuarien du Maroc: cas de l'estuaire de Sebou. Bull Inst Sci 25: 67-75.

26. Ech-chafay $H$, Hachi T, Najy M, Fatimetou Salma MMOS, El kharrim K, et al. (2017) Contribution to the physico-chemical study of the Moulouya waters in the region of Outat El Haj and Missour. J Mater Environ Sci 8(6): 1921-1928.
27. El Morhit M, Fekhaoui M, Serghini A, El Blidi S, EL Abidi A, et al. (2013) Typology of water quality in the Loukkos River estuary (Morocco). Larhyss Journal 12: 7-24.

28. Cherkaoui E, Bayed A (2005) Structure and distribution of the intertidal benthic communities in a North African Estuary: The Bou Regreg Estuary. Mar Life 15(1-2): 29-41.

29. Sarkar S K, Saha M, Takada H, Bhattacharya A, Mishra P, Bhattacharya B (2007) Water quality management in the lower stretch of the river Ganges, east coast of India: an approach through environmental education. J of Cleaner Production 15(16): 1559-1567.

30. Mounjid J, Cohen N, Fadlaoui S, Belhouari A, Oubraim $S$ (2014) Contribution à l'évaluation de la qualité physico-chimique du cours d'eau Merzeg (Périurbain de Cassablanca, Maroc). Larhyss J 18: 31-51.

31. Malki M, Marin I, Essahale A, Amils R, Moumni M (2008) Physico-chemical parameters and bacterial diversity in the Moroccan's Sebou River. J Food Agri Environ 6(1): 132-136.

32. Fekhaoui M (1990) Recherche hydro biologiques sur le moyen Sebou soumis aux rejets de la ville de Fès: suivi d'une macro-pollution et évaluation de ses incidences sur les composantes physiques, chimiques et biologiques de l'écosystème. Thèse Doctorat d'Etat Faculté des Sciences Rabat Maroc 165.

33. El Blidi S, Fekhaoui M (2003) Hydrologie et dynamique marégraphique de l'estuaire du Sebou (Gharb, Maroc). Bull Inst Sci 25: 57-65.

34. Benzakour O (1995) Peuplement benthique associé à la palourde $V$. decussata au niveau d'un estuaire atlantique marocain "Estuaire du Bouregreg". Mém CEA Faculté des Sciences Dhar Mehraz Fès Maroc, pp : 140.

35. Boussalwa E (2001) Description et biotypologie des peuplements d'invertébrés benthiques exposés à la pollution dans la lagune de Nador et dans l'estuaire de Sebou. Doctorat d'Etat Universié Ibn Tofail Faculté des Sciences Kénitra, pp: 156.

36. Lamri D (2009) Physico-chemical and biological characterization of water courses of Moulouya: Water quality assessment using biotic index through a macro-invertebrate-based study. Doctorate thesis, 


\section{Journal of Ecology \& Natural Resources}

Ibn Tofail University, Faculty of sciences, Kénitra, Morocco, pp: 149.

37. Dakki M (1985) Sur le choix des données en bio typologie des eaux courantes par l'analyse factorielle des correspondances. [Selecting Data in biotypology of running waters using correspondence factorial analysis]. Bull Ecol 16: 285-296.
38. El Agbani M (1984) The hydrographic network of basin watershed of BouRegrag River (Moroccan Central Plateau), Biotypology Essay. Univ Claude Bernard Lyon, pp: 147.

39. Badri A (1993) Influence of floods on lotic ecosystems in the High Atlas: A study of perturbations and recolonization mechanisms by algae and invertebrate populations. Univ Cadi Ayyad. Marrakesh pp: 384.

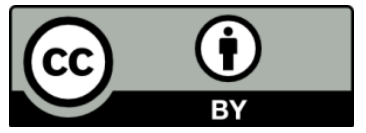

